\title{
STUDI KUALITATIF : FAKTOR PREDISPOSISI SEBAGAI UPAYA PENCARIAN PENGOBATAN PADA KOMUNITAS ADAT TERPENCIL DI DESA BUKIT SUBAN, AIR HITAM SAROLANGUN, JAMBI, INDONESIA
}

\author{
Qualitative study: Predisposing Factors as an Efforts of Health Seeking in Indigenous \\ Community (KAT) in Bukit Suban, Air Hitam Sarolangun, Jambi, Indonesia
}

\author{
Guspianto $^{1}$, Asparian ${ }^{2}$, Evy Wisudariani ${ }^{3}$ \\ 1,2,3Program Studi Ilmu Kesehatan Masyarakat Universitas Jambi
}

\begin{abstract}
Abstrak
Perilaku individu atau kelompok dalam upaya pencarian pengobatan sangat bervariasi yang dipengaruhi oleh jumlah sarana, jenis, metode serta peralatan pelayanan kesehatan yang tersedia. Pada Komunitas Adat Terpencil (KAT) atau Suku Anak Dalam terlihat memiliki keunikan khusus dalam pencarian pengobatan, tentunya menjadi fokus tenaga kesehatan dalam mengupayakan kesehatan masyarakat yang optimal. Selain itu, dari segi pola hidup dan hukum, KAT sangat patuh terhadap aturan adat dan tabutabu yang mengatur perilaku mereka dengan begitu ketat termasuk perilaku pencarian pengobatan. Penelitian ini bertujuan untuk mengetahui faktor predisposisi KAT dalam upaya pencarian pengobatan. Studi Kualitatif dengan wawancara mendalam pada bulan April-September 2019. Informan dalam penelitian ini yaitu Tokoh Masyarakat "Tumenggung", dukun dan petugas kesehatan. Upaya pencarian pengobatan yang dilakukan masyarakat Desa Bukit Suban yaitu Mengobati sendiri (self treatment), Pengobatan tradisional (traditional remedy) dan mencari pengobatan ke unit fasilitas kesehatan. Masyarakat juga masih menganut kepercayaan terhadap penyembuhan penyakit melalui jampi-jampi dan benda-benda yang dianggap sebagai pelindung, serta dewa harimau sebagai roh nenek moyang. Perlunya mengoptimalkan program pelayanan kesehatan yang merata, meningkatkan koordinasi dengan tokoh masyarakat 'Tumenggung' dan rutin dalam mengedukasi masyarakat KAT guna meningkatkan pemahaman dalam meningkatkan derajat kesehatan.
\end{abstract}

Kata Kunci : Pengobatan, Komunitas Adat Terpencil, Prediposisi

\begin{abstract}
The behavior of individuals or groups in seeking treatment varies greatly, which is influenced by the number of facilities, types, methods and health care equipment available. Remote Indigenous Communities (KAT) or Suku Anak Dalam appear to have special uniqueness in seeking treatment, of course, become the focus of health workers in seeking optimal public health. Besides that, in terms of lifestyle and law, KAT is very obedient to the customary rules and taboos that strictly regulate their behavior, including treatment seeking behavior. This study aims to determine the predisposing factors for KAT in seeking treatment. This study used a qualitative study method (indepth interview) which conducted in April - September 2019. Informants in this study were community leader called "Tumenggung" and health worker. Efforts to seek treatment carried out by the people of Bukit Suban Village are self-treatment, traditional remedies and seeking treatment at a health facility unit. People also still believe in healing diseases through incantations and objects that are considered as protection, and the tiger god as the spirit of the ancestors. It is necessary to optimize equitable health service programs, improve coordination with 'Tumenggung' community leaders and regularly educate the KAT community in order to increase understanding in improving health status.
\end{abstract}

Keywords: Medicine, Remote Indigenous Community, Prediposition

Korespodensi : Evy Wisudariani

Email: evywisudariani@unja.ac.id 


\section{PENDAHULUAN}

Perilaku pencarian pengobatan pada masyarakat sangat bervariasi yang dipengaruhi oleh jumlah sarana, jenis, metode serta peralatan pelayanan kesehatan yang tersedia.Perilaku pencarian pengobatan dapat dimulai dari hal yang sederhana seperti mengobati sendiri (self treatment) hingga menggunakan cara pengobatan modern dengan teknologi yang canggih (1).

Perilaku pencairan pengobatan dalam upaya penyembuhan penyakit pada suatu masyarakat dilakukan dengan caracara yang berlaku sesuai kepercayaan masyarakat tersebut dipengaruhi oleh faktor sosial, budaya, dan ekonomi yang mendorong mencari pengobatan yang dibutuhkan (2). Secara umum membagi sistem pengobatan ke dalam dua jenis, yaitu sistem pengobatan modern yang merupakan hasil perkembanan ilmu pengetahuan dan sistepengobatan tradisional yang berasa dari kebudayaan manusia (3).

Keunikan khusus dalam pencarian pengobatan terlihat pada komunitas adat terpencil (KAT) yang keberadaannya juga menjadi fokus dalam peningkatan kesehatan masyarakat. Komunitas Adat Terpencil (KAT) Provinsi Jambi yang disebut juga dengan "Suku Anak Dalam (SAD)" atau "Suku Kubu", atau "Orang Rimba" hidup menyebar dalam kelompokkelompok kecil di dalam hutan-hutan sekunder dalam kesatuan-kesatuan (unit) sosial budaya yang bersifat lokal, serta kurang terlibat dalam jaringan pelayanan sosial, ekonomi, dan politik dari pemerintah $(4,5)$. Pola kehidupan yang masih primitif dengan kondisi sosial ekonomi dan lingkungan yang kurang mendukung menyebabkan KAT rawan terhadap masalah kesehatan. selain itu, dari segi pola hidup dan hukum, KAT sangat patuh terhadap aturan adat dan tabu-tabu yang mengatur perilaku mereka dengan begitu ketat termasuk perilaku pencarian pengobatan (5).

Salah satu lokasi KAT adalah di wilayah hutan Taman Nasional Bukit Dua Belas (TNBD) adalah Desa Suban Kecamatan Air Hitam Kabupaten Sarolangun yang berada dalam wilayah kerja Puskesmas Pematang Kabau. Hasil wawancara awal dengan petugas Puskesmas Pematang Kabau Kabupaten Sarolangun diketahui bahwa meskipun belum diperoleh angka proporsinya secara pasti, umumnya warga KAT saat mengalami sakit masih menggunakan cara pengobatan sendiri dan pengobatan tradisonal terlebih dahulu kemudian jika belum sembuh baru memanfaatkan pelayanan kesehatan modern di puskemas atau tenaga kesehatan lainnya. Namun demikian, pemanfaatan pelayanan kesehatan puskesmas oleh warga KAT cenderung menunjukkan peningkatan yang tergambar dari data jumlah kunjungan warga KAT ke Puskesmas dalam tiga tahun terakhir yaitu sebanyak 67 kunjungan (2016), 84 kunjungan (2017) dan 102 kunjungan (2018) dengan jenis penyakit yang paling banyak diderita adalah penyakit malaria dan disentri $(5,6)$.

Pengetahuan dan pemahaman tentang pelayanan dan pemeliharaan kesehatan mempengaruhi perilaku pencarian pengobatan pada KAT. Ini terkait arus dinamika kehidupan yang semakin terbuka sehingga pola hidup sebagian KAT juga mengalami pergeseran seiring meningkatnya interaksi dan komunikasi dengan dunia di luar hutan. Berdasarkan latar belakang di atas, maka penelitian ini bertujuan untuk melakukan kajian studi kualitatif terhadap faktor predisposisi 
sebagai upaya pencarian pengobatan pada Komunitas Adat Terpecil (KAT) di Desa Bukit Suban Kecamatan Air Hitam, Kabupaten Sarolangun, Jambi.

\section{METODE}

Penelitian ini dilakukan menggunakan metode penelitian analitik yang analisis dilakukan secara kualitatif pada Komunitas Adat Terpencil (KAT) di Desa Bukit Suban Kecamatan Air Hitam Kabupaten Sarolangun yang dilakukan sejak april-September 2019. Teknik pengumpulan data dilakukan dengan wawancara mendalam terhadap Tokoh Masyarakat "Tumenggung", dukun dan petugas kesehatan (7).

Miles dan Huberman dalam Sugiyono (2015) mengemukakan aktivitas dalam analisis data kualitatif dilakukan secara interaktif dan berlangsung terusmenerus hingga tuntas dan informasi dirasakan sudah jenuh dengan aktivitas meliputi: reduksi data (data reduction), penyajian data (data display), dan penarikan kesimpulan/verifikasi (conclusion drawing/verification).

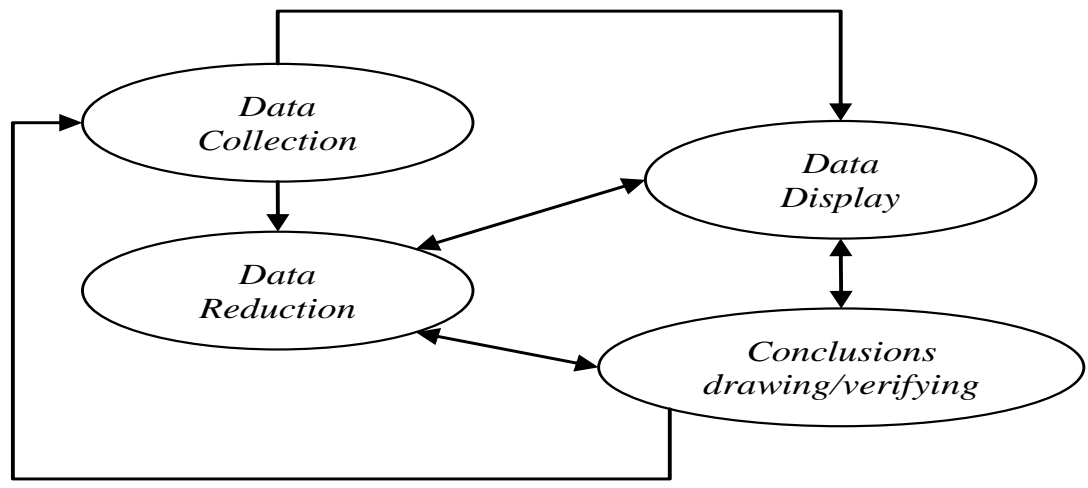

\section{Gambar 1. Komponen Dalam Analisis Aata Kualitatif (Interactive Model)}

\section{HASIL}

Komunitas adat terpencil di Desa Bukit Suban masih mempercayai adat istiadat seperti salah satunya pantangan memakan daging. Selain itu, masyarakat masih memiliki keyakinan untuk upaya penyembuhan penyakit dengan "jampijampi" dan menggunakan benda-benda yang dianggap sebagai pelindung diri. Hal ini dapat dilihat dari hasil wawancara dengan informan.

"iyo dewa harimau kalo ngangkui dewa nyikyong nyanting dewa nyiknyong ha misalnyo eh pokoknyo sesuai dengan namo diolah betaring dewa harimau nyibok dewa laut apo bukan uga uga tu cuman gelar pak jadi itu tergantung namo.."(Dukun)

Hasil wawancara denagan informan didapatkan hasil bahwa masyarakat masih ada obat-obatan tradisional lain yang mereka gunakan, seperti obatan dari hutan yang mereka percayai obatan tersebut di dapat dari nenek moyangnya, dan juga mereka menggunakan sirih merah, hal ini dapat dilihat dari hasil wawancara informan

"kalo ado sirih merah kalo ado sirih merah lebih bagus dak usah lamo - lamo itu awak kasih satu bulan be setiap hari sekali sehari sekali sehari satu bulan foll 
selesai idak ditulung tuhan dikabulkan tuhan sembuh tapi kalo dipakai puskesmas berapo kali awak bawak dak samo sekali pak tambah parah parah kalo ditengok.."(dukun)

Suku Anak Dalam Komunitas Adat Terpencil ini memang masih mengunakan obat-obatan alami, ketika sakit yang mereka rasakan belum parah mereka masih berusaha mengobati dengan obatan alami tersebut, tetapi jika sakit yang mereka rasakan sudah tidak bisa disembuhkan lagi dengan obatan alami mereka minta langsung untuk dibawa ke rumah sakit, hal ini dapat dilihat dari hasil wawancara informan sebagai berikut

"masyarakat yang tinggal dekat Puskesmas mau datang berobat kesini, tapi ada beberapa juga yang minta langsung dibawa ke Rumah Sakit atau minta di rawat, sementara penyakitnya tersebut masih bisa ditangani rawat jalan saja..."(Petugas Kesehatan)

Komunitas adat terpencil di Desa bukit Suban masih menganut kepercayaan mereka terhadap nenek moyang yang mereka sebut dewa hariamau, dewa nyikyong nyenting dewa nyiknyong semua nama tersebut sesuai dengan bentuk mereka yang bertaring dan juga ada dewa laut, gelar yang meraka berikan tergantung dengan namanya. Selain itu mereka menggunakan benda-benda yang berbentuk kalung yang biasanya mereka sebut dengan kalung sebalek sumpah, tapi kalung tersebut tidak semua ibu hamil yang memakai nya karena kalung sebalek sumpah dapat digunakan oleh semua orang tidah hanya ibu hamil saja, hal ini dapat dilihat dari hasil wawancara dari informan sebagai berikut
"Kalo kalung-kalung gitu kan ada sebagian yang pake kalung ada juga yang ngak pake kalung, jarang sih kalung-kalung itu, kalo sebalek sumpah itu kan untuk umum ya, bukan untuk ibuk hamil aja..."(petugas kesehatan)

Dari pernyataan tersebut dapat kita ketahui bahwa komunitas adat terpencil wilayah kerja Puskesmas Pematang Kabau memang benar masih adanya kepercayaan terhadap penyembuhan penyakit melalui jampi-jampi dan benda-benda yang mereka anggap sebagai pelindung, bukan hanya hal itu saja mereka juga mempercayai dewa harimau sebagai roh nenek moyang mereka yang hal ini dijelaskan oleh salah satu dukun ditempat tersebut. Menurut petugas kesehatan setempat memang benar adanya benda-benda yang mereka gunakan dan mereka percayai, benda tersebut biasanya diberinama kalung sebalek sumpah, tapi tidak semua ibu hamil yang memakai kalung tersebut karena kalung tersebut itu biasanya sangat banyak orang biasa atau orang umum yang menggunakannya jadi tidak ada sesuatu hal yang mewajibkan seorang ibu hamil harus memakai kalung tersebut.

Dapat disimpulkan pula, bahwa upaya pencarian pengobatan yang dilakukan masyarakat Komunitas Adat Terpencil Wilayah Kerja Puskesmas Pematang Kabau yaitu Mengobati sendiri (self treatment), pengobatan tradisional (traditional remedy), dan Mencari pengobatan ke unit fasilitas kesehatan (7).

\section{PEMBAHASAN}

Faktor prediposisi ini mencakup pengetahuan dan sikap masyarakat terhadap kesehatan, tradisi dan kepercayaan masyarakat terhadap hal-hal 
yang berkaitan dengan kesehatan, sistem nilai yang dianut masyarakat, tingkat pendidikan, tingkat sosial ekonomi dan sebagainya. Pengetahuan merupakan suatu hal yang sangat dibutuhkan dalam rangka perubahan pola fikir dan perilaku. Pengetahuan adalah kemampuan seseorang untuk mengungkapkan kembali apa yang diketahuinya dalam bentuk jawaban baik lisan atau tulisan. Pengetahuan merupakan domain penting dalam membentuk tindakan atau perilaku seseorang, dimana perilaku yang didasari pengetahuan akan lebih langgeng dari pada perilaku yang tidak didasari pengetahuan (1). Pengetahuan dalam penelitian ini adalah pemahaman KAT tentang upaya pencarian pengobatan pentingnya ditolong tenaga kesehatan dan di fasilitas kesehatan.

Hasil penelitian menunjukan bahwa Komunitas adat terpencil wilayah kerja Puskesmas Pematang Kabau masih mempercayai adat istiadat seperti salah satunya pantangan memakan daging. Selain itu, masyarakat masih memiliki keyakinan untuk upaya penyembuhan penyakit dengan "jampi-jampi" dan menggunakan benda-benda yang dianggap sebagai pelindung diri. Kominitas adat terpencil wilayah kerja Puskesmas Pematang Kabau yang mana masih tinggi nya kepercayaan mereka terhadap nenek moyang yang mereka sebut dewa hariamau, dewa nyikyong nyenting dewa nyiknyong semua nama tersebut sesuai dengan bentuk mereka yang bertaring dan juga ada dewa laut, gelar yang meraka berikan tergantung dengan namanya. Selain itu mereka menggunakan benda-benda yang berbentuk kalung yang biasanya mereka sebut dengan kalung sebalek sumpah, tapi kalung tersebut tidak semua ibu hamil yang memakai nya karena kalung sebalek sumpah dapat digunakan oleh semua orang tidah hanya ibu hamil saja.

Penelitian ini mengungkapkan bahwa bagi masyarakat KAT, seorang dukun sangat dipercaya untuk menolong persalinan oleh karena selain memiliki kepandaian dan pengalaman, juga memiliki kemampuan tertentu yaitu membaca jampijampi (mantera) agar proses melahirkan selamat dan terhindar dari gangguan rohroh jahat. penelitian ini selaras dengan hasil penelitian Donsu \& Korompis (2013) dan Nurhasni, Muslim \& Rosadi (2017) yang menunjukkan bahwa banyaknya persalinan yang ditolong oleh paraji/dukun dibandingkan tenaga kesehatan karena adanya beberapa faktor pendukung sehingga masyarakat lebih memilih dan memanfaatkan dukun dibandingkan tenaga kesehatan (8).

Oleh karena itu dapat kita ketahui bahwa kominitas adat terpencil wilayah kerja Puskesmas Pematang Kabau memang benar masih adanya kepercayaan terhadap penyembuhan penyakit melalui jampijampi dan benda-benda yang mereka anggap sebagai pelindung, bukan hanya hal itu saja mereka juga mempercayai dewa harimau sebagai roh nenek moyang mereka yang hal ini dijelaskan oleh salah satu dukun ditempat tersebut. Menurut petugas kesehatan setempat memang benar adanya benda-benda yang mereka gunakan dan mereka percayai, benda tersebut biasanya diberinama kalung sebalek sumpah, tapi tidak semua ibu hamil yang memakai kalung tersebut karena kalung tersebut itu biasanya sangat banyak orang biasa atau orang umum yang menggunakannya jadi tidak ada sesuatu hal yang mewajibkan seorang ibu hamil harus memakai kalung tersebut. 


\section{KESIMPULAN DAN SARAN}

Dapat disimpulkan bahwa komunitas adat terpencil di Desa Bukit Suban masih menganut kepercayaan terhadap penyembuhan penyakit melalui jampi-jampi dan benda-benda yang dianggap sebagai pelindung, bukan hanya hal itu saja mereka juga mempercayai dewa harimau sebagai roh nenek moyang mereka yang hal ini dijelaskan oleh salah satu dukun ditempat tersebut. Selain itu diketahui pula bahwa upaya pencarian pengobatan yang dilakukan masyarakat Desa Bukit Suban yaitu Mengobati sendiri (self treatment), Pengobatan tradisional (traditional remedy), dan Mencari pengobatan ke unit fasilitas kesehatan.

Perlu mengoptimalkan program pelayanan kesehatan yang merata, meningkatkan koordinasi dengan tokoh masyarakat 'Tumenggung' dan rutin dalam mengedukasi masyarakat KAT guna meningkatkan pemahaman dalam meningkatkan derajat kesehatan.

\section{DAFTAR PUSTAKA}

1. Notoadmodjo, S. 2012. Kesehatan Masyarakat Ilmu Dan Seni. Rineka Cipta, Jakarta.

2. Yuhandini, DS. et al., 2014. Buku seri etnografi 2014 : Goyangan lembut jemari dukun bayi oyog etnik jawa. Jakarta : Penerbitan Balitbangkes

3. Kiefer, C. 2007. Social \& cultural factors related to health part A: Recognizing the impacT. California: Global Health Education Consortium.

4. Keppres. 2014. Peraturan Presiden Republik Indonesia Nomor 186 Tahun 2014 tentang pemberdayaan sosial terhadap komunitas adat terpencil. Jakarta : Kepresidenan Republik Indonesia.

5. Dinsos Provinsi Jambi. 2013. Profil komunitas asat terpencil (KAT) dan program pemberdayaan KAT di provinsi jambi. Jambi: Dinas Sosial dan Katenagakerjaan Transmigrasi Provinsi Jambi.

6. Keppres. 2014. Peraturan Presiden Republik Indonesia Nomor 186 Tahun 2014 tentang pemberdayaan sosial terhadap komunitas adat terpencil. Jakarta : Kepresidenan Republik Indonesia.

7. Sugiyono. 2015. Metode Penelitian Kuantitatif, Kualitatif, dan $R \& D$. Bandung: Alfabeta.

8. Nurhasni, Muslim \& Rosadi. 2016. Faktor-faktor yang Berhubungan dengan Pemilihan Tempat Persalinan oleh Ibu Hamil di Wilayah Kerja Puskesmas Astambul Kabupaten Banjar. Jurnal Kesehatan Masyarakat Vol 1 No. 3. 